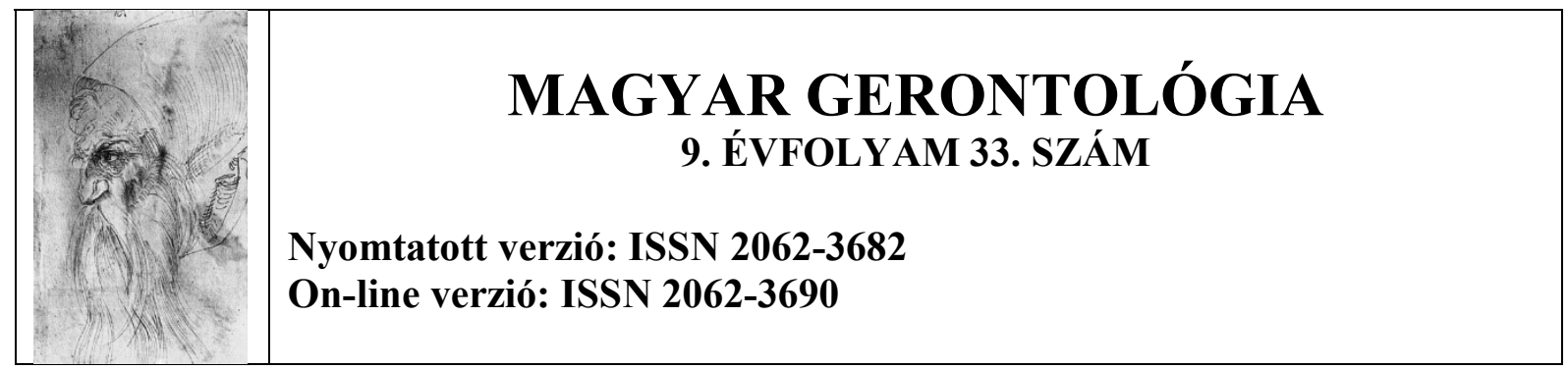

\title{
A TÁPLÁLKOZÁS ÉS A SPORT SZEREPE IDŐSKORBAN A LELKI ÉS A FIZIKAI EGÉSZSÉG MEGŐRZÉSE ÉRDEKÉBEN
}

\section{Lukács Attila}

\section{Összefoglaló} a figyelmet.

A tanulmány az időskori táplálkozás és a testmozgás szerepére, jelentőségére hívja fel

\section{Summary}

This study emphasizes the role of nutrition and the physical exercises in old age.

Mottó: A kor csak a mi agyunkban létezik. Ha nem gondolunk rá, nem létezik.(Mark Twain).

A táplálkozás és a sport, illetve az egészséges életmód minden életkorban kulcsfontosságú, de időskorban az egészséges életmód még inkább kihangsúlyozottá válik.

Mielőtt rátérnénk a táplálkozás és a sport szerepének a hangsúlyozására és részletezésére, fontosnak tartom, hogy beszéljünk az időskorról.

Szinte már közhelynek számít az a megállapítás, hogy a világ népessége elöregedő tendenciát mutat. A népesség elöregedése és a jóléti társadalom között kapcsolat fedezhető fel. A fejlett országokba a 60 év felettiek aránya fokozatosan emelkedik. A WHO szerint 2025-re a 65 év felettiek száma eléri a 600 milliót a világon (Roth-Vincze, 2010, 315).

Magának az időskornak a meghatározása nem egy könnyü feladat, viszont társadalmunk időskornak a 65 év feletti életkort tekinti.

Az életkor meghatározásánál a kronológiai (leélt évek száma), a biológiai (testünk állapota) és a pszichológiai életkort (mennyi idősnek érezzük magunkat) vesszük figyelembe (Roth-Vincze, 2010, 315).

Az öregkorral együtt járnak bizonyos változások, az úgynevezett biológiai, kognitív és pszicho-szociális változások. 
A biológiai változások között említhetjük meg a szervi változásokat:

- a vese kiválasztó müködése több mint a felére csökken

- a máj tömege kisebb lesz, az alapanyagcsere fokozatosan csökken

- a testen áramló vér mennyisége a felére csökken

- az izmok tömege és ereje 30\%-al csökken (Roth-Vincze, 2010, 316).

-- a bőr veszít korábbi rugalmasságából és szárazabbá válik, ami ráncosodáshoz vezet

-- a véredények ellenálló képessége csökken, ennek következtében hosszú ideig kék foltok figyelhetők meg az idősek testén

- a végtagok izomzatai fokozatosan gyengülnek, aminek következtében a végtagok remegni kezdenek, ami az idős embert mind fizikai, mind pszichikai értelemben befolyásolja. Az idős ember szégyelli magát remegő lábai, kezei miatt, és ezt a remegést igyekszik leküzdeni. Ebben az esetben segíthet a rendszeres, az életkornak és az általános egészségügyi állapotnak megfelelő mozgás (Hézser, 2002, 203).

- a csontozat törékenyebbé válik, aminek következtében az idős félni kezd a különböző törésektöl, ami a mozgás lecsökkenését eredményezheti.

- a távollátás felerősödik a közellátás rovására

- tompul a hallás, föleg a magasabb rezgésszámú hangok érzékelése válik nehézkessé

- a szaglás és az ízérzékelés terén is változások figyelhetők meg. A nyelven lévő ízlelőbimbók száma 40-50 egységre esik vissza a fiatalkori 240-250 közötti egységről . Az ízérzékelés romlása miatt az idős emberek az ételeket vagy savanyúnak vagy keserünek érzik.

- a hajszálak elvékonyodnak, megőszülnek, teljesen vagy részlegesen elhullnak

- a fogak kihullnak

- az egész szervezet alkalmazkodóképessége csökken (Hézser,2002, 204).

Az időskori kognitív változások terén eltérőek a vélemények a tudományos világban. Egyesek időskorban a szellemi téren jelentkező hanyatlást hangsúlyozzák ki, míg mások az időskorban is tartó folyamatos fejlődést és kiteljesedést hangoztatják. Tény az, hogy időskorban a kognitív téren jelentkező kisebb vagy nagyobb mértékű hanyatlás elkerülhetetlen. 70 éves kor fölött az agy tömege mintegy 300 grammal csökken, az idegrostok ingerületvezetése 15-25\%-al lelassul a 25 éves életkorhoz képest. Ennek következményeként az információfeldolgozás gyorsasága, felfogása, kódolása és felidézése lelassul.

Időskorban az emlékezeti teljesítmény is romlik, amit a kutatások is alátámasztanak. Az idősek a fiatalokhoz képest gyengébben teljesítenek az emlékezet terjedelmét vizsgáló próbákon (kevesebb szót, számot képesek megjegyezni), ami a rövid távú memória hanyatlását 
jelzi. Ugyanakkor a kutatások értelmében az idősek epizodikus emlékezete is csökken, azaz kevésbé képesek új információkat kapcsolni a már meglévő információkhoz. De romlik a prospektív emlékezet is, ami a jövőben elvégzendö feladatokkal kapcsolatos (pl. mikor kell bevenni a gyógyszert). Viszont a kutatások nem tudták igazolni az idősek implicit emlékezetének a romlását (szó, mondat, vagy képtöredék kiegészítése), de az idősek szemantikus emlékezete, ami az általános ismeretekre vonatkozik, szintén nem mutatott hanyatlást.

A nyelvi képességek terén időskorban a fonológiai (funkcionális hangtani) és lexikális (szókincs) szinten figyelhető meg a teljesítmény csökkenése, illetve a beszédfeldolgozás sebességében is hanyatlás figyelhető meg (Roth-Vincze, 2010, 317-318).

Ugyanakkor James E. Birren és K. Warner Schaie könyvében arról olvashatunk, hogy a kognitív képességek megváltozása ellenére a szókincs gyarapszik az életkorral, és az idősebb felnőttek gazdagabb szókinccsel rendelkeznek, mint fiatalabb társaik egy metaanalízises vizsgálat értelmében. E pozitív változás ellenére a kutatások azt igazolják, hogy időseknek a lexikális információk memóriából való előhívásával akadnak nehézségeik (Birren-Schaie, 2006, 264). Annak ellenére, hogy a kognitív képességek terén hanyatlás figyelhető meg időskorban, ezt azonban kompenzálja az élettapasztalat, a már megszerzett tudás és a kialakult készségek.

Az időskorban pszichoszociális változások is megfigyelhetők. Erik Erikson pszichoszociális elméletében az öregkort az érettség korának nevezi. Ugyanakkor azt mondja, hogy az időskor a visszatekintés, a számadás ideje, amikor sorra vesszük döntéseinket, kudarcainkat, életünk fordulatait. E szakasz krízise az én integritás és a kétségbeesés közötti feszültség. Ha e visszatekintés révén azt látjuk, hogy az életünk értelmes volt, választásaink és tetteink helyesek voltak, akkor elégedettséget fogunk érezni amiatt, hogy amit akartunk azt véghezvittük, és örömmel állapíthatjuk meg, hogyha újra kellene élnünk az életünket, akkor semmin sem változtatnánk. Ez az úgynevezett énintegritás-érzés Erikson szerint. Azonban mint minden egyes szakasznak, így az időskornak is meg van a maga konfliktusa: ez a kétségbeesés. Amikor visszatekintünk elmúlt életünkre és arra ébredünk rá, hogy elvesztegettük az életünket. Amikor úgy gondoljuk, hogy ma már mindent másképp csinálnánk, de sajnos erről már lekéstünk, és azon kesergünk, hogy milyen rosszul alakult az életünk.

Ha az elmúlt évekre, életünk történetére úgy tekintünk vissza, mint egyfajta értékes ajándékra, akkor ez a visszatekintés az én integritás érzésével zárul, és a bölcsesség, mint én minőség jelenik meg. Ez jelentőségtulajdonítást és jóindulatot jelent. Az idős aktívan törődik 
még mindig az élet dolgaival, még akkor is, ha tudja, hogy élete véges (Carver- Scheier, 2006, $307)$.

Az idős embert nagyon sok veszteség éri, ami stresszel jár az egyén életében. Veszteség lehet minden olyan dolognak, tulajdonságnak az elvesztése, megszűnése, ami az egyén számára fizikai, emocionális és pszichológiai szempontból fontosnak számított. A veszteség lehet halál általi veszteség, betegség, fogyatékosság, elszakadás, egzisztenciális veszteség, pszichikus veszteségek (bizalomvesztés, ideálok, eszmék elvesztése) (Roth-Vincze, 2010, 320).

A nyugdíj korhatár elértével a légüres tér érzése keríti hatalmába az idős embert. Nem tud mit kezdeni a rendelkezésére álló sok szabad idővel, s megpróbálja valamivel kitölteni a rendelkezésére álló időt. Fontos lenne az idősek foglalkoztatása, különben a legtöbb idős elkeseredik, lemond önmagáról (Kozma, 2000, 65).

Időskorban is jelentkezhetnek, vagy folytatódhatnak olyan káros időtöltések, magatartási függőségek, mint a szerencsejáték függőség. Ez a szenvedély a megnövekedett idő strukturálásának egyik nem szerencsés formájává válhat. Az időskori, kaszinókban történő szerencsejáték egyik gyakori motivációja éppen egyfajta szociális egészségmegőrzés lehet, aminek a kimenetele kétes értékü. A szerencsejátékok kognitív és érzelmi stimulust jelentenek, (például a majdnem nyertes megerősítések vagy a kezdeti nagyobb nyeremények) (Kurucz és Körmendi, 2012; Körmendi és Kurucz, 2010, míg a személyzet és többi játékosok szociális támogatást is képviselhetnek az idős játékos számára. (Körmendi, 2009; Körmendi, 2011).

Idős korban az egyén elveszítheti társát, aminek következtében a társtalanság, a magány érzése keríti hatalmába. A hosszú ideig tartó folyamatos magány azonban rossz hatással van az egyénre pszichikailag, éppen ezért fontos a közösség keresése és közösség tagjaként a hasznosság érzésének újbóli megtapasztalása (Kozma, 2000, 65).

A fentebb felsorolt időskori biológiai, kognitív és pszicho-szociális változások szükségessé teszik, hogy az egyén még inkább oda figyeljen életmódjára, hiszen a helyes táplálkozás és sport minden egyes életszakaszban, így időskorban is jótékony hatással van a szervezetre és az élet minőségére.

Köztudott, hogy időskorban az immunrendszer folyamatosan gyengül. Csökken a szervezet ellenálló képessége a daganatokkal, vírusokkal, fertőzésekkel szemben. A táplálkozás azonban nagymértékben hozzájárul az immunrendszer megfelelő müködéséhez. A rosszul vagy alultápláltság hatására az immunrendszer legyengül. Az immunrendszer megerősítése érdekében ajánlott az étrend-kiegészítők, fehérjék, hormonok, és egyéb növényi kivonatok szedése. Fertőzések esetén jótékony hatással vannak az immunrendszerre a vitaminok és ásványi anyag kiegészítők. Az A-vitamin a leghatásosabb a fertőzések ellen. A sejtfejlődés 
nélküle nem bontakozik ki. Hiánya következtében csökken a szervezet vírusok és baktériumok elleni védekező képessége. A Béta-karotin szerepet játszik a limphociták számának alakulásában, illetve a káros hatások ellen fellépő sejtek gyarapodásában és működésben. Az E-vitamin globálisan javítja az immunreakciót és aktívabbá teszi idős személyeknél a lymphocitákat. A C-vitamin elősegíti az E-vitamin szint megnövekedését a szövetekben és hozzájárul az immunrendszer javításához. A legfontosabb antioxidáns hatásfokkal rendelkezik. Az antioxidánsként müködő nyomelemek szintén fontosak a szervezet számára, mert az antioxidáns enzimek müködésében is szerepet játszanak. A nyomelemek között említendő a cink, amely a sejtmüködésben játszik szerepet, és helyrehozza a lymphocita képződés zavarait. A szelén, a vas, a mangán a szabad gyökök ellen védenek. A szelén a mell-, tüdö-, máj-, illetve az urológiai rákok megelőzésében is jótékony hatású. De a homeoterápia, illetve a fitoterápia is hasznosnak bizonyul az immunrendszer védekező képessége növelésében. Felső légúti megbetegedés esetén ajánlott a kalória bevitelt csökkenteni és a táplálkozást probiotikumokkal kiegészíteni (Semsei, 2008, 536-538).

Az egészséges táplálkozás korra és nemre való tekintet nélkül mindenkire vonatkozik. A nagy kérdés, hogy ha egészségesen akarunk táplálkozni milyen tápanyagokat vigyünk be a szervezetünkbe? Idős korban a megváltozott szervet, megváltozott étrendet, tápanyagot kíván. Nagyon lényeges a gondos alapanyagok kiválasztása. Nagy fehérjetartalmú, de zsírszegény friss húsok, vegyszer nélküli zöldség- és gyümölcsfélék és teljes kiőrlésü gabonatermékek szerepeljenek a kiválasztott alapanyagok között. Tejből, tejtermékből alacsony zsírtartalmú készítményeket ajánlott fogyasztani időskorban. Még heti 1-2 édesség is, illetve 1-2 gyorsétel, mint hamburger, giros, vagy pizza is belefér az egészséges táplálkozásba. Főzés esetén inkább pároljuk az ételeket, illetve a gőzben fözést, roston, grill-vagy mikrohullámú sütőben történő sütést részesítsük előnyben. Ajánlott sütőzacskókat, alufóliát vagy teflonedényt is használni a konyhában. Főzés során ajánlott a fiatal növények, állatok részeit használni, hiszen ezek könnyebben emészthetőek. A rostosabb, mócsingosabb, zsírosabb részek nehezen emészthetőek, ezért nem ajánlott ezeket idősek ételeinél használni. A tej és tejtermékek nagyon jo fehérje- vitamin-, és ásványi anyag források, könnyen emészthetőek, ezért ajánlottak az idősek számára. Mindezek mellett az úgynevezett fitokemikáliák (növényi vegyületek) növényi eredetü élelmiszerekben vannak és fontos szerepük lehet az egészség megőrzésében, hormonális, gyulladásellenes és antioxidáns szerepük van (Semsei, 2008, 539-540).

Chopra és Simon szerint az étel képes arra, hogy gyógyítson és felüdítsen, az egészséges étel ugyanakkor öregedést gátló orvosság. Fontosnak tartják hangsúlyozni, hogy akkor leszünk egészségesek és akkor élünk egy jobb minőségü és hosszabb életet, ha sok friss zöldséget, 
gyümölcsöt, teljes kiörlésü gabonaféléket fogyasztunk, és minél kevesebb állati eredetü zsírokat viszünk be a szervezetünkbe (Chopra és Simon, 2003, 78-79).

Ugyanakkor az egészség megőrzése szempontjából ajánlott a mediterrán étrend, amelyet a hosszú élet titkának vagy életmentő diétának is nevezik. Nevét a Földközi-tenger mentén fekvő mediterrán országok jellegzetes táplálkozási szokásairól kapta. Történeti háttere 1948-ig nyúlik vissza, amikor a görög kormány a Rockefeller Alapítványt azzal bízta meg, hogy mérje fel a krétai lakosság egészségügyi, gazdasági és szociális helyzetét, hogy az akkor elmaradottnak számító szigetet egy felzárkóztatási programmal felfejlessze. A felmérés szerint a sziget gazdaságilag valóban rossz helyzetben volt, de az átlagéletkor és az átlagos egészségügyi állapot kiemelkedő volt. Az emberek sokáig éltek, kevés volt az infarktus, a daganatos megbetegedés és a túlsúlyos ember. Mindezek hátterében a táplálkozási szokások álltak (www.otvenentul.hu).

De lássuk, hogy miből áll ez az étrend?

Ez a komplex étrend elsősorban a friss idényzöldségekre és gyümölcsökre épít. Ezekből kell minél többet fogyasztani minden egyes étkezésnél ( www.nosalty.hu). A sok zöldség és gyümölcs egyrészt segít a testsúly megörzésében, másrészt magas rost-és vitamintartalmának köszönhetően a szervezet egészségének a megörzésében is segít. Ugyanakkor a gyümölcsöknek, zöldségeknek antioxidáns hatásuk van, amelyek védelmet nyújtanak a daganatos megbetegedésekkel szemben.

Az étrend összetevőjét képezi a teljes kiőrlésű kenyér, tészta és rizs. A tészta durumbúzából készül, ezért gazdag rostokban, vitaminokban és ásványi anyagokban. A durumbúza a vércukorszintet lassabban emeli, a belőle készült tésztába nem kell tojást tenni, így azok koleszterin mentesek. A rostok segítik az emésztést és elengedhetetlenül lényegesek a gyomor-és béltraktus egészséges müködéséhez (dieta-abc.hu/mediterran-dieta).

Egy másik fontos összetevője a mediterrán étrendnek az olivaolaj, amely megvédi az érrendszert az elmeszesedéstől, megakadályozza a zsírok lerakódását az erekben és csökkenti a vér koleszterinszintjét. Az olivaolaj gazdag E-vitaminban, aminek antioxidáns hatása is van, így gátolja a sejtek oxidációját, és meggátolja a daganatos betegségek kialakulását. Megelőzi a magas vérnyomást és a vérrögök kialakulását, a trombózist. (www.otvenentul.hu).

A húsok közül érdemes halat, illetve tengeri herkentyűkből készült ételeket fogyasztani. Ezek segítenek fehérje-, vas- és B12 -vitamin szükségletünk kielégítésében, a halak ugyanakkor a zsírsavak forrásai is. A gyakori halfogyasztás csökkenti az infarktus 
kialakulását (dieta-abc.hu). Ugyanakkor szárnyas húst is lehet hetente egy alkalommal fogyasztani a mediterrán diéta szerint, de havi 1-2 alkalommal vörös húst is lehet fogyasztani. Hozzá tartozik a mediterrán étrendhez 2-3 dl vörösbor elfogyasztása. A vörösbor flavonoid tartalma csökkenti az érelmeszesedés előfordulását, érrendszervédő hatása van. $\mathrm{Az}$ antialkoholisták ki is hagyhatják az étrendböl.

Kisebb mennyiségben a diétába belefér még magok, csírák, diófélék fogyasztása. Kevés tejtermék, illetve sovány sajtok fogyasztása, illetve heti maximum 4 tojás elfogyasztása szintén megengedett. Heti egy alkalomnál nem ajánlott több cukrozott süteményt és csokoládét fogyasztani. ( $\underline{\text { www.nosalty.hu}}$ ).

A mediterrán diéta részét képezi még a rendszeres testmozgás. A sport fontos részét képezi az ideális testsúly elérésének, megtartásának és a jó közérzet kialakításának. Az ideális az lenne, hogy mindennap sportoljunk, de legalább heti három alkalommal legalább egy fél óra sportolás mindenképpen nagyon fontos egészségünk megörzésében. Ez lehet kocogás, intenzív séta, kerékpározás, lényeg az, hogy leljük örömünket is az adott sportban. Lehet az első alkalmak nehezünkre esnek, de ha kitartóak vagyunk akkor rászokunk a sportra, testmozgásra, jól fog esni, sőt ha valaminél fogva kimarad egy alkalom még hiányozni is fog (http://www.vital.hu).

Köztudott tény, hogy időskorban az emberi szervezet alkalmazkodó képessége jelentősen csökken. Az alkalmazkodó képességet fejleszteni lehet a rendszeres testedzés révén. A fizikai aktivitás megszakításos terhelést jelent (terhelés-pihenés) mely nagyon jó hatással van a szervezet alkalmazkodó képességére. A rendszeres testedzés növeli az átlag élettartamot, ugyanakkor kapcsolat mutatható ki a szabadgyökök reakciói és a testedzés között. Becslések szerint egy emberi sejtben naponta 1 millió szabadgyök keletkezik, melyek reaktivitásuk miatt kapcsolatba kerülnek a fehérjékkel, zsírokkal és DNS-el. Ennek következtében a fehérjék elveszítik élettani funkciójukat, a zsírsavakból álló sejt és sejtalkotó membránok áteresztő képességüket megváltoztatják, a DNS pedig a benne tárolt információ átírásával, mutációjával válaszol a szabadgyökös reakciók többségére. A sejtalkotók így oxidatív sérülést szenvednek, és a sejtek, szervek, szervezet funkció hanyatlása következik be.

Laboratóriumi kísérletek igazolták azt, ha idős állatoknak szabadgyök fogó vegyületet adnak, akkor csökken az oxidatív sérülések mennyisége az agyban és javulnak az agyi funkciók. Mindezt a labirintus tesztben elkövetett hibák számával mérték. Miután befejezték az antioxidáns kezelést, az oxidatív sérülés és az agyi funkciók az idős állatok szintjének lett megfelelő, azaz agyi funkcióromlás volt tapasztalható. 
Egy másik kísérletben az antioxidáns kezelés helyett testedzést alkalmaztak, és azt tapasztalták, hogy a testedzés megakadályozta az agyi funkciók romlását, és az oxidatív fehérje sérülése is csökkent. A kísérlet értelmében megállapítható, hogy a rendszeres testedzés az antióxidáns és oxidatív sérülést javító enzimek segítségével csökkenti az oxidatív stresszt, aminek pozitív funkcionális hatásai vannak, és szerepet játszhat az időskori betegségek elkerülésében (Semsei, 2008, 510-512).

A testedzésnek a központi idegrendszerre is jótékony hatása van. 60-ik életév után az agyi müködés terén jelentős hanyatlás következik be, és jelentősen megemelkedik a központi idegrendszert érintő két fő betegség előfordulása: az Alzheimer és Parkinson kóré.

A demencia -ide tartozik az Alzheimer és a Parkinson kór-a memória hanyatlásával és más egyéb kognitív romlással (absztrakt gondolkodás, ítélőképesség, beszéd képességének zavara) együtt járó tünet együttes (Comer, 2005, 607).

A demencia rizikó faktora között szerepel a fizikai inaktivitás. Az idegsejtek száma az életkor előrehaladtával jelentősen csökkenek, megváltozik a fehér és szürke állomány állaga, mindkét állomány veszít keménységéből. Kimutatták, hogy azok az idős emberek, akik sportoltak azoknak a fehér és szürke állománya megtartotta állagát. Ez alapján elmondhatjuk, hogy a sport lassítja az öregkorral járó agylágyulást.

Az fMRI segítsével az is mérhető, hogy a testmozgást végző idősek egy adott feladat elvégzése során több idegsejtet aktivizáltak, mint a velük azonos korú testmozgást nem végző társaik. Majd azokat akik addig semmilyen sportot sem gyakoroltak 6 hónapig edzették és azt tapasztalták, hogy az edzések hatására, amikor egy bizonyos feladatot kellett megoldaniuk náluk is megnőtt az idegsejtek száma, és nagyobb lett a hatékonyság a feladat elvégzésénél.

Fizikai inaktivitás következménye lehet a beta-amyloid lebontott fehérje felszaporodása, ami az Alzheimer kór oka. A mozgás hatására a beta-amyloid mennyisége csökken és megnő a betaamyloid bontásért felelős enzim, a neprilysin aktivitása.

A mozgás révén az agyban a kapillárisok száma is megemelkedik, amely fontos tényező az agyi öregedés ellen (Semsei, 2008, 512-513).

A sport ugyanakkor jó hatással van a szívre és a keringési rendszerre. Idős korban az artériák fala megvastagszik és rugalmatlanná válik a kollagén koncentráció miatt. Ugyanakkor az erek csökkent rugalmassága miatt a perifériális ellenállás is megnövekszik, aminek következtében megnövekszik a vérnyomás is. A lipoproteinek milyensége és mennyisége komoly kockázati tényezőt jelent a szív -és keringési betegségeknél. A trigliceridek és az alcsony sűrüségü lipoprotein (LDL) növekedése és az erek külső falára való kitapadása érszükületet okoz, és a szükebb érkeresztmetszet szívinfarktuhoz vagy agyvérzéshez vezethet. 
A magas koleszerinszint szintén kockázati tényezőnek számít. Az életkor előrehaladtával a szív átméröje is nő, a kamrák közötti fal vastagsága növekszik meg. A rendszeres sport javítja a szívfunkciókat, melynek következtében javul a szív terhelhetősége, csökken a veszélyes triglicerid és LDL mennyisége és növekszik a HDL szint, azaz a magas sűrüségü lipoprotein. Mindez megóvja a szervezetet az érelmeszesedéstől. (Semsei, 2008, 513-514).

A sport csökkenti a stresszt, a szorongást, depressziót, jó fizikai és lelki állapotot eredményez, aminek következtében javul az immunrendszer funkciója. A sport hatására a megbetegedések, fertőzések gyakorisága is csökken, de csökken a megbetegedések és fertőzések időtartama és súlyossága. Hetente 4-5 alkalommal végzett 30 perces séta vagy gyaloglás szintén képes javítani az egészségügyi állapoton. A sport hatására egyes immunalkotók citotikus aktivitása növekszik. A limfociták és neutrofilok száma mintegy 50100\%-al növekszik. A testedzést követően 30 percen belül 30-50\%-ra esik vissza. Az NK sejtek (természetes ölősejtek) vírusok és tumorsejtek elleni védekezésben jelentős citotikus aktivitása 40-100\%-al megemelkedik a sport hatására (Detre, 6-7).

A sport ugyanakkor hatással van a csont-és izomrendszerre. A csontritkulás egyik leggyakoribb időskori megbetegedés, ami elsősorban nőknél fordul elő az alacsonyabb alap csontsürűség miatt. A csontritkulást több tényező idézheti elő az ösztrogén, a D vitamin szint, a Ca felszívódás emésztőrendszeri csökkenése és a mozgásszegény életmód. A csontritkulás következménye növeli a csonttörések előfordulását. A rendszeres sport jelentős szerepet játszik a csontritkulás megelőzésében, mivel az izomkontrakció által kifejtett húzó erő a csontos stimuláló ingert jelent, amely arra készteti az emberi szervezetet, hogy szinten tartsa a csont sürüségét. Időskorban a vázizom mennyisége 40-50\%-al csökkenhet. 60 éves kor után a fizikai aktivitás csökken, mindez az izom mennyiségének a csökkenését is eredményezi. Éppen ezért fontos a testedzés.

Az életkorral csökken a GLUT4 és a vázizom mennyisége, ami cukorbetegséghez vezethet, melyet testedzéssel meg lehet akadályozni vagy késleltetni lehet a betegség előfordulását (Semsei, 2008, 514-515).

A testmozgás az öregedés biomarkereinek többségét képes csökkenteni. Dr. William Evans és Irwin Rosenberg, a Tufts Egyetem munkatársai nyomon követték és dokumentálták a testgyakorlás hatásait. Kutatásuk során megállapították, hogy a mozgás révén az izomtömeg és a fizikai erő nő, a légzési kapacitás és a csontok ellenálló képessége is javul. De az öregedés folyamatát is lassítja a rendszeres testedzés. A testedzés révén javul a közérzet is (Chopra és Simon, 2003, 155-156). 
A szervezetre jótékony hatással vannak a távol-keleti mozgásformák is, mint a tai csi, a csi kung és a jóga, mindezek erősítenek és nyugtatnak. De minden formája a sportnak jótékony hatással van az egészségre és fontos szerepet játszik mind a fizikai, mind pedig a lelki egészség megőrzésében. És ha a sportot és az egészséges táplálkozást összehangoljuk, akkor ezzel minden egyes életszakaszban egy jobb életminőséget fogunk elérni.

\section{Irodalomjegyzék}

1. A tökéletes étrend-mediterrán diéta www.nosalty.hu (2012 július 27)

2. Birren E. J, Schaie W. K. (2006). Handbook of The Psychology of Aging. Elsevier Academic Press, USA

3. Carver S.C, Scheier F.M. (2006). Személyiségpszichológia. Osiris Kiadó, Budapest

4. Chopra, D., Simon, A. (2003). Fiatalodj és élj tovább! Édesvíz kiadó, Budapest

5. Comer, J. R. (2005). A lélek betegségei. Osiris Kiadó, Budapest

6. Detre Z. (2006): A sport egészségmegörző szerepe. hadmernok.hu/archivum/2006/1/2006_1_Detre.pdf

7. Hézser, G. (2002). A Pásztori Pszichológia Gyakorlati Kézikönyve. Kálvin Kiadó, Budapest

8. Koczka K. (2000): Mediterrán diétával egy életre lefogyhat! http://www.vital.hu

9. Kozma, Zs. (2000). Pojmenika. Református Egyház Misztótfalusi Kis Miklós Sajtóközpontjának Nyomdája, Kolozsvár

10. Körmendi A. (2009): A szerencsejáték strukturális és szituációs jellemzői. Alkalmazott Pszichológia 11(3-4): 19-35

11. Körmendi A. (2011): A kóros játékszenvedély kognitív megközelítése. Debreceni Egyetemi Kiadó, Debrecen.

12. Körmendi A., Kurucz Gy.(2010): A „majdnem nyertem” másodlagos megerősítés vizsgálata nem szerencsejátékos mintán. Pszichológia 30 (4): 335-348

13. Kurucz Gy., Körmendi A. (2012): Can we perceive near miss? Journal of Gambling Studies 28 (1): 105-111.

14. Lám Luca: Életet menthet a mediterrán étrend! www.otvenentul.hu (2012.09.02)

15. Mediterrán diéta dieta-abc.hu/mediterran-dieta

16. Roth, M.- Vincze, A. E. (2010). Bevezetés a fejlődéslélektanba. Presa Universitară Clujeană Kiadó, Kolozsvár

17. Semsei, I. (2008). Gerontológia. Debreceni Egyetem, Egészségügyi Kar, Nyíregyháza 
Lukács Attila Levente PhD hallgató

Debreceni Egyetem Humán

Tudományok Doktori Iskola

lukacsattia288@gmail.com 